\title{
0 rio Doce e a emancipação da economia nacional (Brasil)
}

DOI: $10.5935 / 2237-2717.20150001$

\section{Doce River, and the emancipation of national economy (Brazil)}

\author{
Haruf Salmen Espindola \\ Universidade do Vale do Rio Doce (UNIVALE) \\ harufse@gmail.com \\ Governador Valadares \\ Brasil
}

Recibido: 2 de febrero de 2015

Aprobado: 12 de agosto de 2015

\section{RESUMO}

0 artigo é uma revisão de estudos que realizei sobre o rio Doce, nos últimos 20 anos, motivada pelo projeto "As delimitações espaciais na pesquisa em história ambiental". 0 entendimento crítico sobre o conceito de espaço e sobre as implicações das delimitações espaciais para as ciências humanas e sociais aumenta a inteligibilidade sobre as ações e as relações sociais, incluindo os fenômenos socioespaciais, particularmente os de natureza socioambientais.

\section{PaLAVRAS-ChaVe}

Brasil, Rio Doce, história ambiental.

\section{ABSTRACT}

This article reviews studies previously performed by myself on Rio Doce in the last 20 years, motivated by a project named "Spatial boundaries in Environmental History research". Critical understanding on the concept of space and on the implications of spatial boundaries for Human and Social Sciences increases intelligibility on social actions and relations, including social-spatial phenomena - social-environmental phenomena in particular.

\section{KEYWORDS}

Brazil, Doce River, environmental history.

\section{A problemática da escola e o rio Doce}

0 texto que segue é uma reinterpretação de estudos realizados e publicados sobre o rio Doce, nos últimos 20 anos, motivada pelo projeto "As delimitações espaciais na pesquisa em história ambiental", aprovado no edital Universal do CNPq, em 2012. 0 entendimento crítico sobre o conceito de espaço e sobre as implicações das delimitações espaciais para as ciências humanas e sociais aumenta a inteligibilidade sobre as ações e as relações sociais, incluindo os fenômenos socioespaciais, particularmente os de natureza socioambientais. 0 projeto abriu caminho para um diálogo como geógrafos de diferentes concepções, principalmente com as correntes da

\footnotetext{
${ }^{1} 0$ projeto "As delimitações espaciais na pesquisa em História ambiental" é financiado pelo CNPq, Processo: 482250/2012-7. A coordenação é do Prof. Dr. Gilmar Arruda (Universidade Estadual de Londrina - UEL, Paraná, Brasil); os participantes são professores doutores Alessandra Izabel Carvalho (Universidade Estadual de Ponta Grossa - UEPG, Paraná, Brasil); Dora Shellard Correa (Centro Universitário da FIEO - UNIFIEO, São Paulo, Brasil); Ely Bergo de Carvalho (Universidade Federal de Minas Gerais - UFMG, Belo Horizonte, Brasil); Eunice Sueli Nodari (Universidade Federal de Santa Catarina - UFSC, Santa Catarina, Brasil); Haruf Salmen Espindola (Universidade do Vale do Rio Doce - UNIVALE, Minas Gerais, Brasil); Jó Klanovicz (Universidade Estadual do Centro Oeste - UNICENTRO, Paraná, Brasil); José Augusto Drummond (Universidade de Brasília - UnB, Distrito Federal, Brasil); José Augusto Padua (Universidade Federal do Rio de Janeiro - UFRJ, Rio de Janeiro, Brasil); Rogério Ribeiro Oliveira (Pontifícia Universidade Católica do Rio de Janeiro - PUCRJ, Rio de Janeiro, Brasil).
} 
geografia crítica e da nova geografia política. ${ }^{2}$ A abordagem interdisciplinar possibilitou uma mudança de olhar sobre 0 objeto da história e sobre o tempo histórico, mais especificamente sobre a história ambiental.

Como se encontra em Boaventura de Souza Santos, "a escala é um 'esquecimento coerente' que deve ser levado a cabo coerentemente". ${ }^{3}$ Para Racine, Raffestin e Ruffy, ${ }^{4}$ no texto de onde Santos retira a expressão, é necessário que os pesquisadores especifiquem e deixem claro qual a escala que utilizam na pesquisa, pois a "escolha das escalas de análise é arbitrária, muitas vezes aleatória, quase sempre não explicitada". A escala afeta diretamente a realidade representada, à medida que a diminuição da escala aumenta a homogeneidade e, inversamente, a amplificação da escala aumenta a heterogeneidade. Quando maior a escala mais cresce a quantidade de detalhes que se pode observar; quanto menor a escala mais se reduz a quantidade de detalhes que se pode observar. ${ }^{5} \mathrm{~A}$ diminuição progressiva da escala obriga 0 autor/ator da representação a decidir sobre 0 que será agrupado e inserido e 0 que ficará de fora e desaparecerá. Essa decisão não é aleatória, pois atende a intencionalidade do aùtor/ator da representação. É preciso considerar, sempre, as escolhas sobre o que existirá ou deixará de existir na representação como mediadas por relações de poder.

0 Estado, como qualquer organização, são todos atores socioespaciais, cujas decisões são tomadas com base em representações construídas em determinada escala, definida conforme a extensão da área abrangida, ou seja, do campo operatório do ator. Com apoio em Raffestin, ${ }^{6}$ pode-se afirmar que as Ciências Sociais têm examinado a realidade a partir da escala do Estado, quando correto seria considerar genericamente toda "organização dotada de poder político suscetível de se inscrever no espaço". Referindo-se a atividade de pesquisa, Racine et al.7 parte do pressuposto de que o pesquisador também lida com escala quando delimita o objeto de investigação, porém quase sempre sem consciente disso. Não seria possível lidar com a quantidade enorme e incognoscível dos subconjuntos existente na realidade, quando se passa do local para o regional, daí para 0 nacional e, sucessivamente, até abranger o planeta Terra. 0 problema não se encontra na necessidade de escolhas e esquecimentos, mas se existe ou não coerência e consciência sobre o que essas operações produzem; sobre as relações de poder que envolvem; e sobre a natureza relacional dos processos socioespaciais. Como explica Souza Santos, ${ }^{8}$ as diferenças de escala são qualitativas, visto dado fenômeno só se representar em dada escala e, ao mudar de escala, se muda o fenômeno. "A questão que se coloca então é saber se, ao passar de uma escala a outra, as modificações na natureza ou na medida da dispersão serão previsíveis". ${ }^{9}$ A complexidade dos fenômenos exige uma problemática relacional, capaz de tornar inteligível as relações, o poder e suas manifestações espaciais. ${ }^{10}$ Para Racine et al., a categoria "intencionalidade" é decisiva e, portanto, não pode ser negligenciada: "Como primeira aproximação pode-se, pois, definir a escala como uma função do esquecimento coerente que permita uma ação bem sucedida. A escala aparece desde então como um filtro que empobrece a realidade, mas que preserva aquilo que é pertinente em relação a uma dada intenção."11

A história precisa considerar que suas fontes são representações que chegaram ao presente (documentos, testemunhos, memórias etc.) e, mais ainda, que foram construídas a partir de determinadas escalas (pequena, média ou grande), correspondendo à intencionalidade (finalidade), à posição espaço-temporal e à área abrangida pelas operações do ator. Como representação expressa trajetória egocêntrica, pois é construída centrada no autor/ator que a produz. Como ciência do tempo, aparentemente a História não deveria se preocupar com a problemática da escala, mas isso não é verdade, pois a narrativa é afetada pela escala: história local, história

\footnotetext{
${ }^{2}$ Raffestin, Claude. Por uma geografia do poder. São Paulo: Ática, 1993; Santos, Milton. A Natureza do Espaço. Técnica e tempo, razão e emoção. Editora Hucitec, São Paulo, 1996; Massey, Doreen. Pelo Espaço. Rio de Janeiro: Bertrand Brasil, 2008.

${ }^{3}$ SANTOS, Boaventura De Sousa. (1988). Uma cartografia simbólica das representações sociais: prolegômenos a uma concepção pós-moderna do Direito. Revista Crítica de Ciências Sociais(24), 139-172. Disponível em «http://www.boaventuradesousasantos.pt/media/pdfs/Cartografia_simbolica_RCCS24.PDF»Acesso: 21 jun. 2014.

${ }^{4}$ Racine, J. B., Raffestin, C., Ruffy, V. Escala e ação, contribuição para uma interpretação do mecanismo da escala na prátiça da Geografia. Rio de Janeiro, v. 1 , n. 45, p. $123-135$, jan. / mar. 1983.

${ }^{5} \mathrm{Na}$ cartografia a escala é a relação de proporcionalidade entre a realidade e sua representação, ou seja, entre a distância no mapa e a correspondente distância no terreno. Conforme lembram Racine, Raffestin e Ruffy, "quanto mais a escala de uma carta é dita "pequena", mais a superfície do território representada é considerável; quanto mais a carta é dita em "grande escala", mais ela representa de modo detalhado um espaço restrito". Em outras palavras, quanto menor o denominador, maior a escala (1/5000; 1/1000; 1/500: para cada centímetro no mapa são 5000 ou 1000 ou 500 centímetros no terreno) e, consequentemente, se eleva a quantidade de pormenores que se podem representar, visto ser uma pequena área representada, tais como município, cidades, bairros, vizinhança etc.. Quanto maior é 0 denominador, menor a escala e, consequentemente, cresce o número de vezes que a realidade foi reduzida (1/500.000; 1/1.000.000: a realidade foi reduzida 500 mil vezes; um milhão de vezes). Na pequena escala não é possível representar os pormenores e considerar os detalhes, porque se representa uma grande área: país, continente, hemisfério, mundo.

${ }^{6}$ Raffestin, 1994, p. 28.

${ }^{7}$ Racine et al, 1983, p.125-126.

8 Santos, 1988, p.144.

${ }^{9}$ Racine et al., p.125.

${ }^{10}$ Raffestin, 1993, p.31

11 Racine et al., 1983, p.128
} 
regional, história nacional e história geral referem-se às diferentes escalas. Entretanto, se a escala da História é dada pelo Estado, pela simples razão dos historiadores (ou outros pesquisadores) não se preocuparem com 0 problema da escala, todas as histórias acima se reduzirão a uma única história nacional-estatal. A intensidade e momento de consolidação dessa escala nacional-estatal se diferenciaram entre os Estados modernos, porém se concentraram entre a segunda metade do século XIX e a primeira do século XX. No Brasil, mesmo que se possa destacar a importância do Segundo Império, foi no período conhecido como Era Vargas, entre 1930 e 1945, que se consolidou a escala nacional-estatal. No contexto dessa consolidação situaremos o vale do rio Doce, em função do lugar que ocupou nas elaborações discursivas do período.

0 vale do rio Doce entrou na agenda do Estado como parte da temática da "emancipação nacional", a partir da Revolução de 1930. 0 projeto de industrialização, comandado pelo núcleo que detinha o poder do Estado, considerou o vale do rio Doce estratégico para a concretização de sua finalidade. Ao ser alçado a lócus de grandes investimentos de capital (ferroviários, rodoviários, siderúrgicos, mineradores, hidroelétricos etc.) o vale do rio Doce passou a ser representado a partir da escala nacional-estatal. Os atores locais (regional ou estatual) operavam com outras escalas e, consequentemente, produziam e compreendiam a realidade de modos divergentes. Os choques escalares tendem a produzir violentos conflitos socioespaciais, envolvendo principalmente 0 uso do espaço e a destinação dos recursos naturais. 0 risco do conflito e a imobilidade que pode resultar de manifestações dessa potência exigem esforços para o estabelecimento da representação hegemônica, sem a qual o "centro de poder" não conseguiria conduzir uma política coerente. Daí a questão que motivou esse estudo: como o Estado brasileiro, no pós-1930, construiu a representação sobre o vale do rio Doce, enquadrando-0 no projeto de "emancipação da economia nacional"?

0 regime autoritário do Estado Novo (1937-1945) ofereceu facilidades para se impor a escala nacionalestatal, forçando uma desautorização das contradições que emergiam na grande e média escala, por meio do enquadramento unidimensional ao prioritário "desenvolvimento do país". 0 importante é reter que o "poder tende a representar a realidade social e física numa escala escolhida pela sua virtualidade para criar os fenômenos que maximizam as condições de reprodução do poder. A representação/distorção da realidade é um pressuposto do exercício do poder". ${ }^{12}$ Também é importante considerar que o local visto do local é sempre uma grande escala, mesmo que se trate de fenômenos de pequena escala. No local, os pormenores são componentes indissociáveis, para o bem ou para o mal, sendo nesse último caso, pensando na história ambiental, no sentido de cegar e turvar a compreensão; pensando nos atores e no ambiente, no sentido de produzir as condições do "desastre":

A agonia do maior curso d'água do Sudeste brasileiro chegou ao patamar mais crítico da história. Sem força, as águas do Rio Doce, que nascem em Minas Gerais e atravessam o estado até 0 Espírito Santo não deságuam mais no Oceano Atlântico no ponto tradicional. Considerado pelo Instituto Brasileiro de Geografia e Estatística (IBGE) 0 $10^{\circ}$ mais poluído do país, o manancial chegou a um estágio tão grave de seca e assoreamento que a foz - que se alargava por 380 metros de comprimento e tingia a costa capixaba de sedimentos cor de barro - recuou 60 metros continente adentro e se encontra agora como uma lagoa, represada por uma faixa de areia grossa de dois metros de altura. ${ }^{13}$

\section{Rio Doce}

A citação sobre a "agonia do maior curso d'água do Sudeste brasileiro", que não consegue chegar ao mar, é um trecho da matéria publicada, em julho de 2015, pelo jornal "Estado de Minas". 0 assunto foi pauta de diferentes órgãos de impressa nos estados do Espírito Santo e de Minas Gerais, além de ter ganhado cobertura das redes nacionais de televisão. Diferente de ảnos anteriores, inclusive recentes (2011, 2012 e 2013), pautados pelas enchentes, em 2014 e 2015 o que focaliza a atenção é a redução drástica da vazante do rio Doce e os vários cursos d'água que secaram completamente. 0 regime do rio Doce, no entanto, é caracterizado pela alternância entre cheias de verão e vazantes acentuadas na estiagem, como a princesa Tereza da Baviera (1850-1925)

\footnotetext{
${ }^{12}$ Santos, 1988, p.144-145.

13 "Rio Doce deixa de correr na foz original e de desaguar no Atlântico pela primeira vez na história." Jornal Estado de Minas, 12 de julho de 2015. Disponível em: «http://www.em.com.br/app/noticia/gerais/2015/07/12/interna_gerais,667496/rio-doce-deixa-de-correr-na-foz-original-e-de-desaguar-no-atlantico.shtml» Acesso em: 1 março 2015.
} 
registrou, em sua expedição pelo rio Doce, na primeira semana de setembro de 1888: "o nível da água do rio Doce estava tão baixa que durante meia hora, sem sucesso, tentou-se atracar a canoa na margem". Para deixar 0 canal principal do rio e chegar à margem, foi preciso desembarcar num banco de areia e seguir em pequena canoa. Na primeira semana de outubro de 1911, época em que o engenheiro Álvaro da Silveira (1922, p. 497) ${ }^{14}$ realizou seu trabalho no vale do rio Doce ${ }^{15}$, as águas estavam muito baixos e vários cursos d'águas secundários estavam secos: "0 Travessão, que tem um percurso de muitas léguas, estava completamente seco, assim 0 Conceição e outros." Nas localidades da bacia do rio Manhuaçu e dos municípios de Aimorés, Conselheiro Pena, Mutum, entre outros, havia falta de água, apesar de a região ser coberta, em sua quase totalidade, pela florestal tropical. ${ }^{16}$

No decorrer do século XIX o rio Doce motivou o interesse de muitos viajantes estrangeiros, tais como SaintHilaire, Frederico Sellow, Charles Hartt e William Steains. Diversos fatores estão na origem desse interesse, particularmente a floresta tropical, que penetra extensamente pelo interior; as populações nativas, os recursos minerais e os mitos sobre as fabulosas riquezas ali existentes. ${ }^{17}$ Os primeiros registros textuais sobre o rio Doce são do século XVI; na cartografia aparece pela primeira vez em 1540. Nos dois casos, já recebe esse nome peculiar de "Rio Doce", no qual a palavra rio é associada ao nome próprio. Essa situação é excepcional, visto que os demais rios receberam nomes tupi-guarani ou de santos. Nos três séculos seguintes, os registros foram feitos sem a devida identificação do curso do rio. No século XVI a desembocadura do rio Doce dificultou a localização visual de sua existência, em função da curva que ele faz ao se aproximar da praia e correr paralela ao banco de areia, desaguando muito discretamente. As suas águas na estação das chuvas, entre outubro e março, se estendem ao longo de uma grande faixa costeira e penetram extensamente o mar, sendo essa uma das razões apontadas para o nome que recebeu, mesmo antes de se avistar sua foz. Sempre mencionado nas crônicas coloniais e nas obras historiográficas, no capítulo sobre as "entradas" em busca da Serra das Esmeraldas e do Sabarabuçu, o rio Doce foi representado pela cartografia, até o final do século XIX, com um curso muito diferente do seu traçado. ${ }^{18}$

0 percurso do rio já foi calculado em diferentes extensões, variando entre os $977 \mathrm{~km}$, à atual definição de $853 \mathrm{~km}$, com área de drenagem de $83.465 \mathrm{~km}^{2}$, sendo 86\% em território do estado de Minas Gerais e 0 restante (14\%) no Espírito Santo. ${ }^{19}$ A forma da bacia hidrográfica é determinada pelo enquadramento do relevo, que a configura como um trapézio com a base apoiada no sentido SE, em função das serras da Mantiqueira, Caparaó e do Mar; a serra do Espinhaço define os dois lados menores do trapézio, os flanco Oeste e NW; o quarto lado é formado pelas serras de baixa altitude que são os divisores de água com as bacias dos rios Mucuri e São Mateus, compondo o flanco NE. 0 rio Doce corre sobre um leito de pedra tão antigo como o planeta Terra, formando um vale profundo em terreno Arqueano ${ }^{20}$ : a depressão interplanáltica, ${ }^{21}$ abrangendo a área do Parque Estadual do Rio Doce, caracterizada pelo grande número de lagoas; e a depressão periférica, ${ }^{22}$ que corresponde ao médio rio Doce, entre a foz do rio Piracicaba e a do Manhuaçu. ${ }^{23}$ As depressões formam o vale do rio Doce, propriamente dito, caracteriza-se por estreitos terraços e baixadas aluviais, que possuíam, até a década de 1950, vastas áreas de pântanos e zonas lacustres. "O relevo da geologia se traduz na paisagem, pelas formas do relevo; ora a hidrografia se adapta à estrutura, ora se impõe à mesma". ${ }^{24}$ Ambas as depressões se encontram em altitudes muito baixas: $40 \mathrm{~m}$ do nível do mar a cerca de $110 \mathrm{~km}$, em Colatina; $83 \mathrm{~m}$ em Aimorés, divisa entre Minas Gerais e Espírito Santo, cerca de 180km da foz; 235m em Ipatinga, distante aproximadamente 450km da foz; 330m em

\footnotetext{
${ }^{14}$ Silveira, SILVEIRA, Álvaro Astolpho da. Memória Chorographicas. Belo Horizonte: Imprensa Oficial, 1922.

${ }^{15}$ Os engenheiros Álvaro da Silveira e Ceciliano de Almeida realizaram trabalho de campo para fundamentar a posição de Minas Gerais nos litígios de fronteira com Espírito Santo. (CARVALH0, 1953, p. 213-218).

${ }^{16}$ Silveira, p.497.

${ }^{17}$ Espíndola, 2005. Haruf Salmen. 0 Sertão do Rio Doce. Bauru, EDUSC, 2005.

18 (TEIXEIRA, P. 2002, 120-121).

19 (COELHO, 2014, p. 133). COELHO; A. L. N. Compartimentação geomorfológica da bacia do rio Doce: uma atualização. VI Simpósio Nacional de Geomorfologia. Disponível em: «http://www.labogef.iesa.ufg.br/links/sinageo/articles/416.pdf» Acesso: 30 mar. 2014.

${ }^{20}$ A encosta Oeste-Noroeste da bacia do rio Doce é formada por terrenos Algonquiano, ricos em minério de ferro. No Espírito Santo, no último trecho do rio Doce, no município de Linhares, o rio Doce depositou sedimentos que formaram os tabuleiros de geologia terciária e a planície costeira quaternária. (STRAUCH, 1955, mapa entre as páginas 4 e 5$)$

${ }^{21}$ Depressão interplanáltica é uma área baixa circundada por planaltos. Existem onze depressões interplanalticas no Brasil, sendo as mais importantes: Depressão Marginal Norte Amazônico; Depressão Marginal Sul Amazônica; Depressão Sertaneja e do São Francisco; Depressão Periférica da Borda leste da Bacia do rio Paraná; e a Depressão do Vale do Rio Doce.

${ }^{22}$ Depressão periférica é um abaixamento do terreno em relação à área circundante, assemelhando-se ao fundo de uma canoa.

${ }^{23}$ Coelho, 2014.

${ }^{24}$ Strauch, N. (org.) A Bacia do Rio Doce. Estudo Geográfico. Rio de Janeiro: IBGE, 1955. P.5.
} 
Ponte Nova, onde oficialmente começa o rio Doce, ${ }^{25}$ a quase $600 \mathrm{~km}$. Ao se afastar da calha do rio Doce, no entanto, a altitude sobe a patamares de $600 \mathrm{~m}$ a $1200 \mathrm{~m}$, sem contar os picos elevados. 0 rio Doce se assemelha a rio de planície, com o curso lento, mas seu leito rochoso forma corredeiras que impedem a navegação, exceto no trecho do baixo rio Doce, entre Regência (foz) e Mascarenhas, no município de Baixo Guandu, no Espírito Santo, onde se construiu uma usina hidroelétrica. ${ }^{26}$

0 rio Doce tem características diferentes, comparadas a outros rios brasileiros que ganharam destaque na historiografia. Apesar do seu longo curso e de penetrar extensamente no interior, chegando à região central do estado de Minas Gerais, não cumpriu funções típicas que se esperaria de um rio com seu tamanho e área de drenagem. Essa característica se torna mais significativa se considerarmos o contexto da Era Vargas, quando o rio São Francisco foi celebrado como "rio da unidade nacional", por Orlando Carvalho. ${ }^{27}$ Até a década de 1970, quando eu estava na escola, se era obrigado a decorar os afluentes das duas margens do São Francisco, o rio da unidade nacional. Orlàndo Carvalho começa associando o destino do Brasil à direção das águas dos rios, que por serem tolhidos pelas serras do Mar e Mantiqueira, se direcionavam para 0 oeste, levando a civilização para 0 interior dos sertões, distantes e isoladas do litoral. 0 rio São Francisco, no entanto, era a exceção, pela direção divergente dos demais, estando-Ihe reservadả a função de ser o rio da unidade nacional. 0 rio Doce, diferente do rio São Francisco, mesmo penetrando fundo no interior, não cumpriu nem auxiliou no processo de penetração e ocupação dos sertóes. No lugar de contribuir para a integração nacional, o rio Doce serviu mais de obstáculo e limite, inclusive por razões de salubridade.

Quando os colonizadores portugueses chegaram às costas do atual Espírito Santo, se estabeleceram nas desembocaduras dos rios, exceto na foz do rio Doce, que permaneceu desabitada. Eles simplesmente mantiveram o padrão da ocupação tupi-guarani, que evitava o rio Doce. 0 trabalho de arqueologia de salvamento no médio rio Doce, em função da área de inundação da Usina Hidrelétrica de Aimorés, identificou elementos da cultura material tupi-guarani, com datação acima de 750 anos. Entretanto, quando da chegada dos colonizadores, a muito esses povos haviam abandonado os assentamentos às margens do rio Doce. ${ }^{28}$ Os estabelecimentos criados pelo governador de Minas Gerais, no século XVIII, com objetivo de prevenir incursões indígenas à zona aurífera, se Iocalizaram distante da calha do rio Doce. Apesar do rio Doce - rio do Carmo levarem a cidade de Mariana e vila Rica, os nativos do tronco macro-gê, que habitavam a bacia do rio Doce, não utilizavam o rio como caminho, mas vias terrestres. Da mesma forma, quando os luso-brasileiros iniciaram o movimento de ocupação da bacia do rio Doce, buscaram as terras altas dos afluentes. As tribos que frequentavam as margens do rio Doce se retiravam antes o início da estação das chuvas. Os primeiros assentamentos junto ao rio Doce foram guarnições militares, a partir das ordens régias de 1808, determinando a ocupação do vale do rio Doce e promoção da navegação. Os quarteis das divisões militares e os poucos habitantes que se escabecearam junto deles, não passaram de lugarejos pobres, clareiras em trechos isolados da floresta, junto às corredeiras ou confluência de afluentes importantes. Isso, pelo menos, até o final do século XIX. ${ }^{29}$

0 naturalista Saint-Hilaire, ${ }^{30}$ que esteve no vale rio Doce por duas vezes, em 1816-17 e 1824, se impressionou com a "fraqueza da sociedade frente à natureza na zona do rio Doce". 0 inglês William Steains (1888), que no final do século XIX, subiu o rio Doce da foz até 0 alto curso do rio, descreve uma paisagem formada por florestas e mais florestas. No foi o rio que possibilitou a ocupação do vale do rio Doce, mas a construção da Estrada de Ferro Vitória a Minas (EFVM), iniciada em 1903. A estrada atingiu Figueira (atual Governador Valadares), em 1910, numa altitude de 165m, distante 330km de Vitória. A ferrovia segue margeando o rio Doce até a confluência do rio Piracicaba, numa altitude de $233 \mathrm{~m}$, distante $469 \mathrm{~km}$ de Vitória; prosseguindo pelas margens desse afluente até 0 antigo arraial de São José da Lagoa, no quilometro 534, na altitude de 509m. A EFVM cumpriu o papel histórico atribuído aos rios brasileiros na ocupação dos sertões, funcionando como "ferrovia de penetração".

\footnotetext{
${ }^{25} 0$ rio Doce recebe seu nome quando as águas do rio Piranga (formador) se encontram com as do rio do Carmo, no município de Ponte Nova, MG.

${ }^{26}$ A navegação do rio Doce sempre foi limitada, mesmo no baixo rio Doce, onde se promoveu a navegação de pequenas embarcações a vapor, tipo gaiola, com até 20 metros de comprimento, entre Regência e Colatina, na primeira metade do século XX. Essa navegação era irregular, até mesmo para as grandes canoas empregas nesse trecho do rio, visto ser praticamente impossível a navegação franca na vazante, quando se forma grandes bancos de areia. De Figueira (Governador Valadares) ao Porto de Souza (Mascarenhas), 16 km depois da divisa com o Espírito Santo, antes da Estrada de Ferro (1910) houve navegação por canoas, principalmente transportando sal.

${ }^{27}$ Carvalho, (1937, p. 9) Orlando Magalhães. 0 rio da unidade nacional: 0 São Francisco, Companhia Editora Nacional, São Paulo, 1937.

${ }^{28}$ Baeta A. M. ; ALONSO, M. ; PILÓ, H. . As Ocupações Humanas no período Pré-colonial no Médio Vale do Rio Doce. In: Era Tudo Mata. REZENDE, M. \& ALVARES, R. (ORG.) Consórcio Aimorés (CEMIG/VALE), Belo Horizonte, 2009. p. 20.

${ }^{29}$ Espíndola, 2005; Mattos, Izabel Missagia de. Civilização e revolta: os Botocudos e a catequese na Província de Minas. Bauru: Edusc-Anpocs, 2004.

30 Saint-Hilaire, A. 1974, p. 176-177).
} 
Outras "regiões" da bacia do rio Doce estiveram vinculadas a processos históricos diferentes. Na porção meridional se formou duas áreas de influência da Estrada de Ferro Leopoldina: a primeira surge com o ramal que ligou o Rio de Janeiro à cidade de Manhuaçu, aonde chegou em 1915; a segunda ligou o Rio de Janeiro à cidade de Caratinga, aonde chegou em 1930. No primeiro caso houve a extensão da cafeicultura de Carangola para 0 vale do rio Manhuaçu e serra do Caparaó; no segundo, se expandiu a cafeeira pelos vale dos rios Caratinga, Matipó e Cascas, na direção do rio Doce. A porção setentrional da bacia do rio Doce sofreu a influência pela estrada de rodagem que ligou Figueira (Governador Valadares) a Teófilo Otoni, inaugurada em 1934, ao cortar as extensas matas denominadas de "pela macaco", provavelmente, pela alta incidência de malária. A rodovia ligou as estações de duas ferrovias: EFVM e Estrada de Ferro Bahia-Minas, gerando um forte estímulo para a expansão da pecuária bovina de tradição baiana, na direção do rio Doce, proveniente dos vales do Jequitinhonha e do São Francisco.

A porção Sudoeste e Oeste da bacia do rio Doce, que formam as antigas áreas de ocupação do século XVIII, se ligavam diretamente à Belo Horizonte, principalmente pela construção de diversos ramais da Estrada de Ferro Central do Brasil. A capital mineira também estendeu sua influência na direção do vale do rio Doce, graças a conexão entre a EFVM e a Central do Brasil, na vila de São José da Lagoa (cidade de Nova Era). As antigas zonas auríferas, no entanto, têm diferenças entre si, ao se comparar as áreas de influência de São João Del Rei, Ouro Preto, Sabará e Serro, sendo as duas primeiras na porção meridional e as duas últimas na porção setentrional da bacia do rio Doce.

Em 1943-44, a construção da rodovia federal Rio-Bahia, cujo traçado no sentido Sul-Norte, propiciou a integração da bacia do rio Doce à cidade do Rio de Janeiro. Permaneceram duas exceções: a região costeira do Espírito Santo e as terras que se estendem para o norte do rio Doce, na direção da bacia do rio São Mateus. Na área costeira formada pelos tabuleiros e planície quaternária, município de Linhares, estendendo-se para o norte do Espírito Santo, o fator decisivo foi a ligação rodoviária (atual BR 101), particularmente a partir da inauguração, em 1954, da ponte sobre o rio Doce, em Linhares, pelo presidente Getúlio Vargas. A extensa área ao norte do rio Doce e a bacia do São Mateus forma a zona do Contestado, em função do litígio entre os estados de Minas Gerais e Espírito Santo, resolvido pelo acordo final entre os dois governadores, em 1963. ${ }^{31}$ Essa área foi a última "zona pioneira", para onde avançavam as frentes de ocupação. ${ }^{32}$

Com 0 avanço das ferrovias e abertura das estradas de rodagem, os colonos que se estabeleceram nos terrenos de mata, não apenas proprietários, mas também dezenas de milhares de posseiros, fizeram da venda da madeira de lei, dormentes, lenha e carvão vegetal a capitalização inicial para a abertura das lavouras de café. ${ }^{33}$ Com 0 esgotamento dos solos, as terras davam lugar aos pastos e à pecuária bovina extensiva. A exceção foi 0 médio vale do rio Doce, entre as cidades de Aimorés e Governador Valadares, seguindo para o norte acima dessa última cidade, até Teófilo Otoni, aonde a venda da madeira facilitou a implantação das fazendas de criação de gado bovino, sem passar pelo estágio da agricultura. 0 movimento inicial de ocupação da bacia do rio Doce pode ser datado do final do século XIX, a partir das terras altas e, gradativamente, descentro para altitudes menores, em direção ao vale do rio Doce, propriamente dito. Eram comunidades de vizinhança que se estabeleciam em clareiras abertas na mata, cuja produção de subsistência se baseava na ajuda mútua entre vizinhos, com troca de trabalho e mutirão. A valorização das terras provocada, particularmente, pela ligação que se estabeleceu com o Rio de Janeiro (rodovia federal Rio-Bahia), induziu a expansão da pecuária bovina, a concentração de terras e, do pondo de vista jurídico, a substituição das posses pela propriedade privada. Com a valorização das terras cresceu a pressão sobre as comunidades de vizinhança, que entraram em processo de dissolução, convertendo-se seus membros em meeiros agregados das fazendas de criação de gado bovino. ${ }^{34}$

A força do capital se faz presente por meio dos grandes investimentos siderúrgicos, induzidos pelo governo de Minas Gerais, a partir influência de Artur Bernardes (1875-1955). Entre 1925 e 1944, aproveitando as oportunidades oferecidas pela ferrovia, água, minério e matas, se implantou o parque siderúrgico com a tecnologia do carvão vegetal, além de dezenas de fábricas de ferro gusa. Em 1937 a Companhia Belgo-Mineira inaugurou

\footnotetext{
${ }^{31}$ Espíndola, Haruf Salmen. Território e geopolítica nas Minas Gerais do século XIX. Cadernos da Escola do Legislativo, v. 11, p. 71-88, 2009.

${ }^{32}$, Walter Alberto Egler realizou o trabalho de campo na "zona pioneira ao norte do rio Doce", nos anos de 1949 e 1950, com orientação do geógrafo alemão Leo Waibel. (EGLER, 1951)

${ }^{33} 0$ impacto negativo da extração de lenha foi ainda maior para a floresta, pois a lenha era a principal fonte de energia, destinada à estrada de ferro, siderúrgicas, olarias, panificadoras, caldeiras industriais e consumo doméstico, de uma população que crescia aceleradamente nas décadas de 1940 e 1950. (Strauch, 1958, p. 98; Rache, 1957, p. 80).

${ }^{34}$ Espíndola, 2010Haruf Salmen. Apropriação de Terras Devolutas e Organização Territorial no Vale do Rio Doce: 1891-1960.. In: Haruf Salmen Espindola; Jean Luiz Neves de Abreu. (Org.). http://www.univale.br/central_arquivos/arquivos/territoriosociedademodernizacao_eletronico.pdf. Governador Valadares: Editora Univale, 2010, v. Único, p. 19-58.
} 
sua grande siderúrgica a carvão vegetal, onde antes funcionava a fábrica de ferro de Monlevade, e introduziu 0 reflorestamento à base de eucaliptos. Em 1944 foi criada a Companhia Aços Especiais Itabira - ACESITA, na localidade de Timóteo, cerca de $80 \mathrm{~km}$ abaixo de Monlevade. As siderúrgicas desencadearam intensa atividade carvoeira, junto às margens do rio Doce, por onde corriam os trilhos da EFVM, e depois em todo o médio rio Doce. As siderúrgicas produziram carvão vegetal nos seus gigantescos latifúndios, particularmente a Companhia Belgo Mineira, com 235.610 ha de terras, além dos seus agentes comprarem de centena de particulares. A BelgoMineira induzia a concentração das terras com o objetivo de evitar negociar com milhares de pequenos proprietários ou para fugir das incertezas jurídicas de negociar com milhares de posseiros. ${ }^{35} \mathrm{Em} \mathrm{1962,} \mathrm{finalmente,}$ realizou-se a histórica reivindicação dos mineiros: a Usinas Siderúrgicas de Minas Gerais S.A. (USIMINAS), com tecnologia do carvão mineral: iniciou sua produção, nas instalações localizadas na confluência entre o rio Doce e 0 Piracicaba, dando origem a cidade de Ipatinga. ${ }^{36}$

A atividade de mineração no vale do rio Doce se instalou ligada à escala global, criada pela Segunda Guerra Mundial, sob a preponderância dos EUA. Também se liga à escala nacional, associada à supressão dos direitos dos estados tributarem as exportações e, ao mesmo tempo, à separação entre propriedade do solo e do subsolo, além de outros dispositivos do Código de Minas (Decreto n. 24.642, de 10 de jülho de 1934). Com 0 ataque japonês a Pearl Harbor e a entrada dos americanos na guerra, o alinhamento do Brasil se tornou estratégico para os EUA. Além da borracha da Amazônia e das bases aéreas do Nordeste, os americanos se voltaram para o vale do rio Doce, interessados nas reservas de minério de ferro e de mica. Em 1942, com os Acordos de Washington, o presidente Getúlio Vargas obteve 0 apoio dos EUA e da Grã-Bretanha para encampar as minas de minério de ferro, a EFVM e todo restante da Companhia Brasileira de Mineração e Siderurgia (CBMS), criada por Percival Farquhar, em 1939, para substituir a Itabira Iron.

0 plano dos controladores da Brazilian Hematite, quando criaram a Itabira Iron em 1911, foi promover a exportação em larga escala do minério de ferro. Nada ocorreu nesse sentido nem mesmo as obras da EFVM prosseguiram no ritmo dos oito anos anteriores. A EFVM tinha avançado cerca de 50 quilômetros, em 1920, quando Farquhar conseguiu do governo federal a assinatura do contrato que permitiria a realização dos planos da Itabira Iron. Mais uma vez, no entanto, isso não se concretizou. 0 presidente de Minas Gerais, Artur Bernardes, não ratificou 0 contrato e, além disso, o estado de Minas estabeleceu tarifas de exportação de minério que inviabilizavam, na prática, as exportações. Nos anos seguintes, embates acirrados marcaram a luta contra 0 contrato entre a Itabira Iron e o governo federal, no que ficou conhecido como "caso Farquhar". A controvérsia durou até 0 decreto de 11 de agosto de 1939, que o declarou caduco. ${ }^{37}$

Em 1942 o governo federal criou a Companhia Vale do Rio Doce - CVRD, 38 dando-Ihe ao mesmo tempo uma missão nacional de emancipação do Brasil: "A história da nossa emancipação econômica tem seu primeiro capítulo na constituição mesmo da Companhia Vale do Rio Doce..." 39 Também fez constar no estatuto a responsabilidade de promover 0 desenvolvimento da bacia do rio Doce. ${ }^{40} \mathrm{~A}$ nova empresa, com apoio técnico e financeiro dos EUA, iniciou a reforma da EFVM, modernizando-a para o transporte de minério em grande escala. Como parte deste esforço de cooperação, o governo dos EUA também auxiliou o governo brasileiro, com recursos

\footnotetext{
${ }^{35}$ StrauchNey. Zona Metalúrgica de Minas Gerais e vale do rio Doce. Guia de excursão nº . 2. Rio de Janeiro: Conselho Nacional de Geografia, 1958 . p.170.

${ }^{36}$ Strauch, 1955; Paula, João Antônio de. Dois Ensaios sobre a Gênese da Industrialização em Minas Gerais: A Siderurgia e a Indústria Têxtil. In. II Seminário sobre a Economia Mineira 2. Diamantina, 1983. Anais, Belo Horizonte: CEDEPLAR/FACE/UFMC, 1983; Rache, Athos de Lemos. Contribuição ao estudo da economia mineira. Rio de Janeiro: José Olimpio, 1957.; Gomes, Francisco Magalhães. História da Siderurgia no Brasil. Belo Horizonte; São Paulo, Itatiaia; Edusp, 1983; Costa, Heloisa Soares de Moura. Vale do Aço: da produção da cidade moderna sob a grande indústria a diversidade do meio ambiente urbano. Belo Horizonte, UFMG, 1995. (Tese de Doutorado). ${ }^{37}$ A astúcia de Farquhar estava longe de se esgotar, mesmo nos seus 75 anos, pois em resposta ao decreto federal, se associou com seis brasileiros e, mantendo 0 controle da EFVM, obteve 0 arrendamento das minas de Itabira. A Companhia Brasileira de Mineração e Siderurgia, criada por Farquhar, mesmo precariamente conseguiu extrair, conduzir por caminhões até a ferrovia e exportar uma pequena quantidade de minério de ferro, dando a isso grande publicidade. Entretanto, estava em curso outro processo que iria atropelar o esforço empreendido por Farquhar: as negociações de Vargas com Washington. Com 0 Decreto-Lei ${ }^{0} 4.352$, de $1^{0}$ de junho de 1942 , que "encampa as Companhias Brasileiras de Mineração e Siderurgia S.A. e Itabira de Mineração S.A". e cria a Companhia Vale do Rio Doce, finalmente parecia que Farquhar estava fora do jogo. Todavia, com seus 80 anos, ainda deu uma última cartada, fundando no vale do rio Doce, com dois dos sócios anteriores, a Companhia Aços Especiais Itabira (Acesita), em 1944, próximo ao rio e junto aos trilhos da EFVM, a cerca de 110 quilômetros de Itabira.

${ }^{38}$ Em 2007, a CVRD retirou a identificação de origem e adotou o nome de Vale SA. Conforme a empresa informou em coletiva à imprensa: A ideia é que todas as unidades de negócios abandonem as expressões "Companhia Vale do Rio Doce", "Rio Doce" ou a sigla CVRD. (R0SA, 2015).

${ }^{39}$ Carvalho, B. de. 0 Vale de ferro tem nome de Doce. Aconteceu. Rio de Janeiro, n. 60, p. 22-27 e 63, nov. 1958. Diretor: Roberto Marinho. Rio Gráfica e Editora Ltda. 1958, p. 27)

${ }^{40}$ Em 1955 a Vale destinou os primeiros recursos para atender a obrigação estatutária de apoia o desenvolvimento do vale do rio Doce, contudo a sua presença não influenciou efetivamente nos rumos do desenvolvimento regional (MEDEIROS, 1969).
} 
e pessoal especializado, nas ações de saneamento do vale do rio Doce e erradicação da malária, em duas frentes: Projeto Rio Doce e Projeto Mica. ${ }^{41}$

A importância da exportação do minério de ferro se deu depois no pós-guerra, porém outro minério teria papel relevante: a mica. ${ }^{42} \mathrm{~A}$ presença desse mineral no vale do rio Doce atraiu estrangeiros de diferentes procedências, particularmente entre Governador Valadares e Aimorés, se estendendo da margem para o norte, em direção ao vale do rio Mucuri. As fontes indianas de mica foram cortadas pelos submarinos alemães, forçando os EUA a buscar uma substituição. A importância de Governador Valadares para a exportação de mica pode ser visto nas palavras do médico Ladislau Sales, referindo-se ao que encontrou quando chegou nessa cidade:

Um fato que me chamou a atenção em Governador Valadares quando eu cheguei aqui, é que a Guerra havia começado há poucos meses e já havia uma comissão japonesa, adquirindo mica, que era um material precioso para confecção de avião. E algum tempo depois, veio uma comissão americana, muito mais poderosa, com 0 mesmo objetivo...

Então, a comissão americana dispunha de uma quantidade de máquinas! Foi a primeira vez que Valadares conheceu uma patrola. [...] Então, o indivíduo chegava lá e dizia: "Eu quero construir uma estrada". Eles diziam: "perfeitamente" e mandava o trator abrir a estrada. Antes de saber se tinha mica, pra mostrar serviço perante os superiores. ${ }^{43}$

Em 1942, com apoio técnico e financeiro é implantada uma verdadeira indústria da mica, centrada na cidade de Governador Valadares. Nas palavras de Ladislau Sales, referindo-se aos americanos: "Fornecia o que quisesse; eles queriam mica a qualquer preço. Então o sujeito dizia: "ah!, mas eu preciso de um jipe". Leva um jipe... "Eu preciso de um trator pra fazer a estrada pro caminhão chegar lá". Leva, leva também o caminhão..." Os arrendatários ou proprietários das jazidas também faziam o beneficiamento, em instalações com dezenas de operárias e crianças, mas principalmente controlavam os serviços de centenas de pequenas oficinas ou de trabalhadoras domésticas, espalhadas em fundos de quintais pelos bairros pobres da cidade e povoados rurais. Nos anos de 1950, conforme Strauch, ${ }^{44} 0$ produto era, na sua maior parte, exportado para os EUA.

As diferentes dinâmicas econômicas da bacia do rio Doce (agricultura, pecuária, siderurgia, carvão vegetal e indústria da madeira) não favoreciam, no entanto, a integração entre as várias zonas. 0 esgotamento dos solos provocava um movimento em busca de novas terras de mata, forçando o deslocamento na direção das terras baixas do rio Doce. Essas foram as últimas a serem efetivamente ocupadas, marcando o ponto de encontro das correntes provenientes do Sul e do Norte, respectivamente agricultura cafeeira e pecuárias bovina; bem como das correntes do Leste e do Oeste, respectivamente das antigas zonas mineradoras de Minas Gerais e das zonas serranas de colonização europeia do Espírito Santo. Nem a atividade mineradora, com a criação da Companhia Vale do Rio Doce e a modernização da EFVM, modificou o cenário anterior. Na bacia do rio Doce não se formou uma rede urbana integrada, mas centros comerciais e industriais autônomos: junto à EFVM/rio Doce sobressaem a) Governador Valadares; b) Ipatinga, Coronel Fabriciano e Timóteo; c) Ponte Nova; e d) Colatina; junto a Estrada de Ferro Leopoldina, os dois polos urbanos tradicionais, Caratinga e Manhuaçu. Esses centros urbanos polarizaram zonas próprias, cujo crescimento se deveu a atração crescente que exerceram sobre a população rural circunvizinha, que sofriam com o esgotamento dos cafezais ou das pastagens. Governador Valadares se destacou pela extensão de sua força de atração, menos como fator de integração e mais como polo de atração de imigrantes da bacia do rio Doce.

Essa tendência fragmentadora e tendente ao esgotamento da dinâmica econômica não deve ser interpretada interpretação puramente pelos processos sociais, pois tem relação com as características naturais, marcadas por grande diversidade. 0 capital e o Estado não são suficientes para explicar a configuração territorial baseada no latifúndio e na pecuária de extensiva de corte, nem o crescente êxodo para as cidades, nas décadas de 1950-

\footnotetext{
${ }^{41} 0$ saneamento e a instalação e manutenção de serviços urbanos básicos ficaram a cargo do Serviço Especial de Saúde Pública (SESP), agência federal desvinculada da influência dos governos locais (VILARINO, 2008).

${ }^{42}$ Mica, do latim micare (brilho), é um termo genérico aplicado ao grupo dos minerais constituído por silicatos hidratados de alumínio, potássio, sódio, ferro, magnésio e, por vezes, lítio. A mica permite separação em lâminas muito finas e flexíveis; pode apresentar transparência próxima ao vidro; tem baixa condutividade térmica e elétrica; resistência a mudanças abruptas de temperaturas, rigidez dielétrica e estabilidade química. Isso permite muitas aplicações industriais, em setores tão diferentes como cosmético, elétrico, eletrônico, aeronáutico, sendo o melhor isolante termoelétrico e térmico para diversas aplicações, inclusive servindo como vidro em fogões, aquecedores e portas corta fogo.

${ }^{43}$ Entrevista com Dr. Ladislau Sales, realizada em Belo Horizonte, 14/12/2001, por Haruf Salmen Espindola e Joana Darc Germano Hollerbach. Acervo Particular.

${ }^{44}$ Strauch, 1955, 121-122)
} 
1960. Os fatores naturais de geologia, pedologia, geomorfologia, hidrografia, climatologia e fitogeografia criavam diferenças interna a bacia do rio Doce e, consequentemente, configurava várias zonas naturais específicas. A cultura do café foi o elemento comum da bacia do rio Doce, exceto pela zona de predomínio da pecuária extensiva ao norte de Governador Valadares, nas duas margens da rodovia federal Rio-Bahia.

0 uso do território de significativa diversidade natural com o mesmo padrão técnico e ocupação de solo, originados de regiões de geografia distinta, resultou no esgotamento das atividades econômicas, porém em ritmos e durações diferentes. Estabeleceu-se um padrão marcado pelo envelhecimento precoce da zona pioneira, num prazo menor que uma geração, forçando o deslocamento em ritmo acentuado da frente de pioneira, até o limite da disponibilidade de terras públicas na bacia do rio Doce. "As diversas análises feitas nestes solos, numa verdadeira escala de tempo de utilização, mostram que, uma vez retirada a vegetação, e possível obter-se altos rendimentos agrícolas, que podem cair assustadoramente se a fertilidade existente for apenas a resultante daquela vegetação florestal." Assim, uma lavoura podia não passar de 10 anos, depois de ter começado a decair já nos primeiros anos; mesmo em condições melhores, não ultrapassava 15 anos para a lavoura do café e mais 5 anos, com lavoura de subsistência, escodando-se em 20 anos. Com o fim do uso agrícola podia ocorrer duas situações: formatação de pastagem de capins africanos ou, conforme a altitude, clima e acidez da zona, invasão de samambaias. ${ }^{45}$ A zona de predomínio da pecuária extensiva, ao norte de Governador Valadares e no médio rio Doce, se caracterizá pela passagem das matas diretamente para as pastagens, com predomínio do capim colonião, sem uma fase intermediária de uso agrícola do solo. Nesse caso também se deu 0 esgotamento dos solos em prazo relativamente curto, em função das exigências de nutrientes do capim colonião e das práticas de manejo do gado e das pastagens: 46

A década de 1950 é particularmente significativa, pois pode identificar na bacia do rio Doce todos os estágios simultaneamente: 1) zonas deprimidas, tais como as áreas de mineração aurífera, do século XVIII; e as que se se formaram no século XIX, a partir de arraiais auríferos isolados - alto rio Doce, no sudoeste da bacia, e zona de Guanhães e Peçanha, no noroeste do médio rio Doce; 2) zonas onde a cafeicultura foi substituída pela pecuária; 3) zonas em que a cafeicultura predominava, mas a mudança para a pecuária havia iniciado; 4) zona em que 0 café estava no auge; 5) zona em que a frente pioneira avançava, na qual a exploração madeireira está no auge e crescia a cafeicultura; 6) zonas de domínio da pecuária, sem que houvesse 0 estágio agrícola; 7) zonas com especificidades próprias, tais a zona cacaueira no Espírito Santo e zona dos Tabuleiros, no baixo rio Doce; zona de domínio da siderurgia e zona de influência direta da EFVM, correspondendo ao médio rio Doce; 8) zona de mineração ferrífera que se implantava nas antigas áreas de mineração de ouro, entre Ouro Preto e Serro, particularmente a área de atuação da Companhia Vale do Rio Doce - CVRD, em Itabira e no vale do rio Doce, propriamente dito; 9) zona de conflito de limites entre Minas Gerais e Espirito Santo, conhecida como Contestado, entre outras particularidades. Essas diferenças zonais se justapõem ou sobrepõem espacialmente, como resultado da influência combinada de fatores naturais, socioeconômicos, culturais, étnicos e históricos. ${ }^{47}$

Em 1951, o Conselho Nacional de Geografia (CNG), considerando fatores geográficos, históricos e étnicos, dividiu a bacia em oito diferentes regiões, subdivididas, por sua vez, em 16 zonas específicas. Essa regionalização considera as diferenças marcantes que existem entre 0 alto, médio e baixo Doce, que são as bases para a primeira subdivisão. No relatório publicado pelo IBGE, coordenado por Ney Strauch, ${ }^{48}$ esse esclareceu que a excessiva divisão também se devia as singularidades geológicas, pedológicas, geomorfológicas, hidrológicas, climáticas e fitogeográficas, bem como fatores socioeconômicos, socioculturais e étnicos da ocupação humana. Nesse sentido, as diferenças seriam a marca mais forte da bacia do rio Doce, dificultando impedindo um tratamento homogêneo:

A área, onde se enquadra a bacia do rio,Doce, não é uma região homogênea. Aí, nem mesmo o rio pode ser considerado como fator de unificação, como no caso do São Francisco. A bacia do rio Doce caracteriza-se mesmo pelas diferenças, de área para área, dos aspectos físicos como o relevo e a geologia, o clima e a vegetação, dos fatores humanos como as atividades econômicas e a distribuição da população. ${ }^{49}$

\footnotetext{
45 (STRAUCH, 1955, p. 153-158)

${ }^{46}$ EspíndolaH. S. ; WENDLING, Ivan Jannotti. . Elementos biológicos na configuração do território do rio Doce. Varia História (UFMG. Impresso), v. 24, p. 177-197, 2008.

${ }^{47}$ (STRAUCH, 1955)

${ }^{48}$ Id., 29-30)

${ }^{49}$ (d. 1955, 29-30)
} 
As considerações acima são ainda mais significativas frente à tendência atual de se das bacias hidrográficas unidade de análise, de planejamento e de gestão. ${ }^{50}$ Essa passa a ser mais uma escala, entre diversas outras que são operadas pelo Estado (microrregião, mesorregião, macrorregião, região sanitária, territórios da cidadania, região de saúde etc.). "É certo que o Estado persegue uma lógica de uniformidade", mas para ordenar, controlar e gerir o território ele cria diferentes malhas, conforme as diferentes intenções do poder. "É inteiramente da lógica do Estado construir uma imagem de diversidade que ele assenta sobre a uniformidade." 51 Nesse sentido, se afirma a importância do historiador considerar as diferenças de escalas e estratos de tempo, para não cair na armadilha da linearidade e da ideia de progresso. A bacia hidrográfica não passaria de mais uma regionalização que é dita, mas não vivida, se não ocorrer uma mudança da perspectiva espaço-temporal. Isso exige considerar a escala e a problemática relacional, para que possa emergir um ambiente complexo, compostos por elementos de ordem humana e não humana.

0 vale do rio Doce, que estava na pauta nacional, desde a década de 1920, será objeto da ação direta do Estado, com a criação da CVRD, em 1942. Encontramos na obra do coronel Salm de Miranda, "Rio Doce (Impressões de uma época),"52 os sinais das tensões que se formaram na bacia do rio Doce entre os interesses externos (empresas capitalistas, especuladores, madeireiros etc.) e interesses locais. ${ }^{53}$ Também é possível perceber que são contradições entre escalas diferentes e entre diversos estratos de tempos, nos quais e com os quais os atores externos e locais desenvolvem suas ações. Salm de Miranda (1949, p. 35-36) definiu o "Rio Doce" como um "cadinho", devido à diversidade étnica de sua formação. ${ }^{54}$ Essa imagem é parcialmente contrariada pelo próprio autor, pois sua tese se fundamenta na estratificação étnica e na falta de integração os diferentes processos sociais que caracterizam a bacia do rio Doce. Em sua opinião a ocupação da bacia do rio Doce se deu por processos espontâneos: "Ali, sem nenhum planejamento, sem nenhum trabalho previamente organizado, as matas vão caindo ao passo tardo da rotina; extrai-se o que a natureza criou, sem nenhuma elevação do teor econômico daqueles recantos". 55

Os interesses locais seriam aqueles que Salm de Miranda (1949, p. 35 a 37) chama de "nacionais" e "brancos". Inicialmente as terras florestais do rio Doce foram ocupadas pelos nacionais, cuja composição étnica era de negros e de mestiços (conhecidos como roxos). Os brancos, muitos imigrantes vindos da Europa, ${ }^{56}$ chegaram depois e tomaram o lugar dos negros e roxos, que acabaram como empregados. Os nacionais e brancos podem ser identificados, respectivamente, com a frente de expansão demográfica, iniciada nos fins do século XIX, e com a frente pioneira, no sentido dado pelo geógrafo Leo Waibel. ${ }^{57} \mathrm{Na}$ opinião do autor, no entanto, ambos sofriam o descaso do Estado e o impacto negativo dos "interesses externos", cuja única intenção era levar as "riquezas naturais". Os representes dos interesses externos foram os administradores, engenheiros, médicos, técnicos e trabalhadores qualificados, brasileiros e estrangeiros, responsáveis pela implantação dos grandes projetos de investimento de capital (exploração mineral, construção de hidroelétricas e infraestrutura viária, siderurgia e saneamento).

Na década de 1940, o vale do rio Doce foi alçado a uma posição importante na estratégia estatal de modernização e industrialização brasileira. Fiel ao espírito nacionalista do tenentismo, ele afirma ser a população local frágil frente aos poderosos interesses externos originados do Rio de Janeiro, São Paulo e exterior, especificando as grandes companhias, os especuladores de terra e madeireiro. Em sua opinião, ${ }^{58}$ o governo

\footnotetext{
50 Coelho, p. 132; Carvalho, Rodrigo Guimarães de. As bacias hidrográficas enquanto unidades de planejamento e zoneamento ambiental no Brasil. Caderno Prudentino de Geografia, Presidente Prudente, n.36, Volume Especial, p. 26-43, 2014. p. 29; Leal, Antonio Cezar. Planejamento ambiental de bacias hidrográficas como instrumento para 0 gerenciamento de recursos hídricos. Entre-Lugar, Dourados, MS, ano 3, n.6, p 65-84, 2. semestre de 2012. p. 69 e 80; Monica F. A.; PORTO, Rubem La Laina. Gestão de bacias hidrográficas. Estudos Avançados [online]. v. 22, n.63, p. 43-60, 2008. p. 44-45).

51 Raffestin, 1993, p. 182.

${ }^{52}$ Miranda, Salm. Rio Doce (impressões de uma época). Rio de janeiro: Biblioteca do Exército, 1949.

${ }^{53}$ Salm de Miranda, quando ainda era tenente, foi afastado do Exército pelo envolvimento na rebelião de 1922, no Rio de Janeiro. Ele se mudou para o vale do rio Doce, no Espírito Santo, contratado como agrimensor para a demarcação da fazenda de um primo. Ele aproveitou sua estadia pra conhecer a região e a realidade dos agricultores imigrantes e nacionais. Essa estadia e a viagem pela EFVM, descendo o vale do rio Doce, forneceram as bases para o livro "Rio Doce (Impressões de uma época)". RAMOS, Adauto. Salm de Miranda - General e escritor paraibano. João Pessoa: Sal da Terra, 2013.

${ }^{54} 0$ cadinho serve para fundir ou calcinar minérios; no sentido figurado é o lugar onde as pessoas e coisas se misturam ou se fundem.

55 (MIRANDA, 1949, p. 67).

${ }^{56}$ A região de imigração europeia, a que se refere Salm de Miranda, é formada pelo vale do rio Doce, entre Resplendor (MG) e Colatina (ES); pelas bacias dos afluentes da margem direita (Manhuaçu, Guandu e Santa Joana) e esquerda (São José e Pancas); e pela bacia do rio São Mateus, ao norte, para onde se dirigiu a frente de expansão, a partir dos anos de 1930.

${ }^{57}$ Espíndola, Haruf Salmen. Apropriação de Terras Devolutas e Organização Territorial no Vale do Rio Doce: 1891-1960.. In: Haruf Salmen Espindola; Jean Luiz Neves de Abreu. (Org.). http://www.univale.br/central_arquivos/arquivos/territoriosociedademodernizacao_eletronico.pdf. Governador Valadares: Editora Univale, 2010, v. Único, p. 19-58. p. 20-21).

${ }^{58}$ Miranda, 1949, p.31-32.
} 
federal nada fazia, pois estaria interessado apenas nas riquezas minerais para "solucionar o problema econômico nacional", sem lembrar que a região "tem direito de ser beneficiada": Só duas atividades foram ali planejadas: primeiro a Estrada de Ferro Vitória a Minas; depois a extração do minério. Nenhuma delas beneficiou ainda a terra, ou o homem da bacia; e, para elas, está certo, porque no seu planejamento não houve mesmo a cogitação da terra ou do homem da bacia. ${ }^{59}$

\section{O Rio Doce e a Independência Nacional}

Em 1943, finalmente, a ferrovia iniciada em 1903 chegou ao seu destino na cidade de Itabira, aonde se encontravam as reservas de minério de ferro. 0 ano anterior foi 0 divisor entre dois tempos: 0 primeiro, que encerrava, tinha começado com o controle da ferrovia, em 1910, por capitalistas ingleses; o segundo, que iniciava, começou com o Decreto-Lei n. 4.352, de $1^{0}$ de junho de 1942, que criou a Companhia Vale do Rio Doce. 0 primeiro tempo é marcado pela luta dos mineiros contra o capital estrangeiro, que havia comprado os terrenos em Itabira, ricos em minério de ferro, e assumido o controle da EFVM. A oposiçã̃o se intensificou, a partir do governo do presidente de Minas Gerais, Artur Bernardes (1918-1922), quando o empresário norte-americano Percival Farquhar se associou a Itabira Iron Ore Company, em 1919. 0 segundo momento é marcado pela nova conjuntura iniciada em 1937, com 0 advento do Estado Novo: fortalecimento do Estado nacional e processo de modernização e industrialização brasileira. A mudança do nome do antigo arraial de São José da Lagoa, criado em 1703, aonde os trilhos da EFVM chegaram em 1932, oferece um sentido simbólico para esse corte entre os dois tempos. São José da Lagoa, em 1943, passou a se chamar Nova Era e, desta forma, marca a um só tempo a ideologia do Estado Novo e o horizonte de expectativa, no qual se situou o vale do rio Doce: a emancipação da economia nacional.

Na década de 1940 o vale do rio Doce entrou para a agenda do governo federal, como demostra as expedições geográficas de estudo empreendidas com patrocínio do CNG/IBGE. 0 interesse se concentrou na geomorfologia, climatologia, geologia, solos e geografia humana, incluindo a cartografia. ${ }^{60} \mathrm{~A}$ importância do vale do rio Doce se expressou nos artigos publicados, em 1944, por diversos números do Boletim Geográfico (15, 16, 17, 19, 20, 21), editado pelo CNG. Em 1947, no número 49, o Boletim Geográfico publicou o estudo de reconhecimento geográfico, levantamento de coordenadas e estudos de geografia humana. Em 1951, a Revista Brasileira de Geografia publicou 0 artigo do próprio Leo Waibel, em conjunto com Walter Egler e Pedro Pinchas Geiger, sobre Zona Pioneira ao norte do Rio Doce. Foi também, em 1951, que a CVRD firmou convênio com 0 IBGE, no qual se atribuiu ao CNG a tarefa de realizar estudos sobre a bacia do rio Doce, com objetivo de verificar "0 estado atual dos conhecimentos sobre aquela extensa área do país". 0 relatório final foi publicado pelo IBGE, em 1955, com o título "A Bacia do Rio Doce: estudo geográfico". ${ }^{61} 0$ interesse se confirma com 0 apoio governamental para a realização do XVIII Congresso da União Geográfica Internacionál (IGU), na cidade do Rio de Janeiro, em 1956. Entre as excursões que se realizaram dentro da programação do evento, constou a excursão de número 2 - "Região Metalúrgica de Minas Gerais e o Vale do Rio Doce", cujos guias foram publicados em inglês e francês. ${ }^{62}$

Os vários estudos apontam um quadro geográfico de enorme diversidade, porém os fatores destacados são aquelas que interessam economia nacional e ao projeto conduzido pelo Estado. A escala nacional comanda as pesquisas e enquadra a região numa visão idealizada de desenvolvimento. No contexto em que o Estado se fortalecia, o CNG e o IBGE ocuparam posição chave na produção de conhecimento e nas formulações políticas, nas décadas de 1940 e 1950. Coube aos geógrafos, junto com outros especiialistas, papel importante na materialização da vontade estatal, no seu objetivo de encontrar a malha regional que melhor permitisse a produção de conhecimento, o ordenamento e a gestão do território nacional. As excursões organizadas para $18^{\circ}$ congresso da IGU, no total de nove roteiros, expressão essa orientação. A confecção dos "livros-guias" em francês e inglês não apenas atendia a necessidade da maioria dos participantes, que eram estrangeiros, mas tiveram 0 claro

\footnotetext{
${ }^{59} \mathrm{Id}$.

${ }^{60}$ Abrantes, ABRANTES, Vera. Era preciso redescobrir o Brasil. Terra Brasilis (Nova Série), n. 3, 2004. Disponível em http://terrabrasilis.revues.org/982?lang=es. Acessado em 11 de julho de 2015.

${ }^{61}$ Os estudos foram coordenados pelo geógrafo Ney Strauch, chefe da Seção Regional Leste do CNG, e além de outros geógrafos, contou com a participação da empresa "Sociedade de Engenharia Química e Agrícola Ltda." e de um economista designado pela CVRD. (Strauch, 1955, p. IX e X)

620 guia em português foi publicado em 1958. Strauch, 1958.
} 
objetivo de projetar uma determinada imagem do Brasil para o exterior: diversidade como expressão da unidade e grandeza territorial do Brasil. A formação e os trabalhos dessa geração de geógrafos brasileiros contaram com a orientação de estrangeiros, especialmente dos franceses Pierre Deffontaines e Pierre Monbeig, a partir da Universidade de São Paulo e Universidade do Brasil (atual UFRJ). Também se destaca o alemão Leo Waibel, professor nos EUA, contratado pelo CNG, em 1945. A difusão do conhecimento, que permitiu consolidar esse movimento geográfico, foi garantida pelos periódicos "Revista Brasileira de Geografia" e "Boletim Geográfico" ${ }^{63}$

Os estudos geográficos são realizados a partir da perspectiva do Estado nacional e responderam ao contexto marcado pela orientação nacionalista. Como observa Espindola, ${ }^{64}$ o período inaugurado em 1930 se caracterizou, no campo intelectual, pela vontade expressa de aprofundar o conhecimento sobre o território nacional, de acabar com a separação entre litoral e sertão e pelo ideal de modernização do Brasil. Expressões comuns à época, como "novo tempo" e "nova mentalidade", manifestavam uma espécie de autoconsciência da "geração nascida com a República", como se encontra em Vicente Licínio Cardoso, no prefácio da coletânea "À Margem da História da República" (1924). Como escrevia Prudente de Moraes Neto na revista Cultura Política (Revista Mensal de Estudos Brasileiros), ${ }^{65}$ com o pseudônimo de Pedro Dantas, na seção "Literatura de Ideias", realçando a nova mentalidade como superação do "sentimento de inferioridade" que até então prevalecia no Brasil. 0 adjetivo "novo", largamente utilizado no pós-1930, indicava o avanço no caminho da superação do atraso, quando o nacionalismo real tomou o lugar do nacionalismo superficial "verde-amarelo". 0 nacionalismo real se caracterizaria pela verdadeira "preocupação em conhecer o Brasil, suas dificuldades e potencialidades, a fim de fazê-lo superar a estagnação e progredir sem 0 ufanismo de achar que este era 0 'melhor país do mundo'". ${ }^{6}$ Para Mercedes Dantas $^{67} 0$ nacionalismo "torna-se, em consequência, uma força criadora capaz de renovar povos, de erguer impérios, a mais poderosa arma espiritual dos dias contemporâneos". No editorial de abertura do primeiro número de Cultura Política (CP) se encontra o objetivo programático da revista: o Brasil escolheu os rumos do seu futuro e as "páginas desta Revista procurarão definir e esclarecer esse rumo". ${ }^{68}$

Entre os 53 números que saíram ininterruptos de CP, entre 1941 e 1945, se encontram 23 que incluem 0 vale do rio Doce nas temáticas abordadas. Em duas edições, de dezembro de 1943 e janeiro de 1944, a revista publicou uma "reportagem especial" com o título "O Vale do Rio Doce". ${ }^{69}$ Sempre presente dos discursos de Getúlio Vargas ou nas matérias sobre as realizações do Estado Novo, o vale do rio Doce comparece, principalmente nas temáticas da industrialização, siderurgia, recursos minerais e Companhia Vale do Rio Doce. 0 vale do rio Doce se torna um trunfo importante no projeto de "emancipação da economia nacional": 0 Presidente Getúlio Vargas ... abrindo o vale do rio Doce e dando curso às riquezas que se concentram no Planalto (Minas Gerais), tornando centro da economia do Brasil de amanhã. (...) 0 Brasil se integra em si mesmo e, abrindo 0 caminho do rio Doce, realizará o que não se julgava possível concretizar numa só geração. ${ }^{70}$

A "reportagem especial" de Cultura Política sobre o vale do rio Doce fixou um enredo que pode ser encontrado em publicações posteriores, produzidas nos níveis locais, estadual e nacional. A temporalidade utilizada por CP pode ser interpretada pelo que Koselleck chama de "minimum temporal que define 0 antes e 0 depois". ${ }^{71}$ Esse "minimum temporal" seria a Revolução de 1930: momento de rompimento que separou 0 "presente de ontem" e o "atual". Como aparece nas palavras do modernista Rosário Fusco: "Não sabíamos nada de nós e vivíamos numa procura dramática de nós mesmos. Mesmo errado, nosso passado era infinitamente

\footnotetext{
${ }^{63}$ CamargoAlexandre de Paiva Rio. A Revista Brasileira de Geografia e a organização do campo geográfico no Brasil (1939-1980). Revista Brasileira de História da Ciência, Rio de Janeiro, v. 2, n. 1, p. 23-39, jan | jun 2009; Kohlhepp, Gerd. A importância de Leo Waibel para a geografia brasileira e 0 início das relações científicas entre 0 Brasil e a Alemanha no campo da geografia. Revista Brasileira de Desenvolvimento Regional, Blumenau, 1 (2), P. 29-75, Primavera de 2013.; Abrantes, 2014.

64 Santos, 1988, p. 139.

${ }^{65}$ A revista Cultura Política (CP) representou um dos momentos mais conscientes do núcleo no poder do Estado pós-1930, cujo período culminante foi o Estado Novo (1937-1945). A publicação, iniciada em março de 1941, sob a direção de Almir de Andrade, reflete a definição no campo político, depois de anos de confronto e compromissos instáveis (ESPINDOLA, 1988, p. 105-108). Ela não se destinava aos setores populares, mas dirigia-se aos estratos intelectuais e formava opinião, possuindo um formato acadêmico acentuado e um padrão editorial elevado, comparado a outras publicações da época. A revista está estruturada em seções temáticas, que abrangem o político, o social, a economia, os problemas militares, a estrutura jurídica e constitucional, as atividades governamentais e a "evolução social, intelectual e artística". Cada seção é aberta com explicações sobre os assuntos ali tratados e os objetivos a que se propõem; cada artigo é precedido de um resumo de seu conteúdo e da identificação do autor.

${ }^{66}$ Espíndola, 1988, Haruf Salmen. A história de uma formação sócio-econômica urbana: Governador Valadares. In: Varia História/ Revista do Departamento de História, Programa de Pós Graduação, FAFICH/UFMG. Belo-Horizonte, n. 19, nov. 1998, pp. 148 -163. p. 139).

67 Dantas Mercedes. Os regimes políticos e a realidade social do Brasil. Cultura Política (Rev. Mensal de Estudos Brasileiros). Rio, 1(5): 36-43, jul., 1941, p. 43.

68 Andrade, Almir. Evolução Política do Brasil. Cultura Política (Revista Mensal de Estudos Brasileiros). V. 01, n.. 1, mar., 1941,, p. 8).

${ }^{69}$ Cultura Política (Revista Mensal de Estudos Brasileiros). V. 03; N. 35, dez. de 1943; e Cultura Política (Revista Mensal de Estudos Brasileiros). V.. 04, n. 36, jan. de 1944.

${ }^{70}$ ECONOMIA DOS ESTADOS. Cultura Política. Rio, v. 2, n. 15, p. 131-144, maio, 1942, p. 140

${ }^{71}$ Koselleck, $(2014$, p. 23)
} 
superior ao presente de ontem."72 № passado estava a formação histórica da "unidade nacional", consolidada pelo Império. 0 "presente de ontem" era a República Velha, com seu liberalismo importado, que fragmentava a unidade nacional. Para CP (1943, p. 123 e 125) a Revolução de 1930 despertou o Brasil para "um sentido objetivo" e, por isso, a realidade nacional estava sendo tratada com realismo: "coordenação dos elementos para 0 aproveitamento racional das fontes naturais de riqueza do país". Ao promover o rompimento com o "presente de ontem" teria criado "uma mentalidade nova", capaz de "incrementar, a todo o custo, a produção industrial nacional".

A revista CP, ao utilizar diferentes tempos, busca determinar o sentido da história pela contraposição entre avanço/progresso e atraso/retrocesso. Com uma estratégia discursiva histórico-explicativa, busca-se dar ao leitor uma consciência da necessidade da modernização e industrialização do Brasil, conduzida pelo Estado. Constroem-se quatro tempos distintos: o passado, 0 presente de ontem, 0 atual e 0 futuro. Com o primeiro se constrói uma narrativà sobre a gênese da nacionalidade, a unidade territorial e a evolução do Brasil, cujo enredo é centrado em três valores principais: centralização, ideal unitário e progresso. Esses valores foram decisivos para se vencer os elementos desagregadores, que ameaçavam a unidade do Brasil: forças centrífugas, isolamentos e localismos. A diversidade da natureza era positiva, porém as diferentes territorialidades e "regionalismos" eram vistos negativamente, como fragmentação e fator de enfraquecimento da nacionalidade, pois fazia do Brasil uma "colcha de retalhos". 0 passado serve para enquadrar discurso histórico-doutrinário de cunho ideológico e nacionalista, avesso ao ideário liberal da República Velha. No "presente de ontem" o futuro do Brasil estava ameaçado, pois tudo conspirava contra a unidade e organização nacional. Os conceitos de unidade e organização nacional podem ser lidos como unicidade e ordenamento territorial e, desta forma, como "território nacional", mercado interno e gestão efetiva do Estado.

0 tempo "atual" era do avanço/progresso, pois o Estado assumira a responsabilidade de promover a modernização e industrialização do Brasil. 0 "presente de ontem" era o tempo do atraso/retrocesso, no qual predominava o Brasil agrário-rural e a fraqueza diante das nações industrializadas. 0 tempo atual era o "novo": novo Brasil, nova ordem, nova era, nova política, novo trabalhador, homem novo etc. 0 adjetivo servia para indicar que o Brasil estava num novo tempo e seguia na direção do futuro, ou seja, do progresso e da grandeza Brasil, com unidade nacional, a sociedade organizada, país industrializado, grande potência e civilização (modernidade). 0 tempo atual também representava o reencontro com a evolução histórica e que se "reconstruía o Brasil". Como aponta Espindola, ${ }^{73}$ a associação entre "novo" e "reconstruir" assinala o limite da modernização conduzida pelo Estado, pois o "novo" deve preservar o "passado" (evolução histórica). 0 "novo" é uma afirmação da modernização e industrialização do Brasil e, ao mesmo tempo, uma negação do liberalismo da República Velha e do ideal de destino agrícola ("presente de ontem"); "reconstruir" não deixa de ser um retorno a um "passado" idealizado (tradição), porém seu sentido último é afirmar que a mudança e o novo devem ocorrer dentro da ordem, do respeito à autoridade e da garantia da propriedade privada. Portanto assinala uma aliança entre a modernização e a conservação, mais especificamente, entre a sociedade urbano-industrial capitalista e a estrutura agrária herdada do passado colonial.

Nesse contexto discursivo o vale do rio Doce, pela riqueza em minério de ferro e pela EFVM, ocupou lugar importante. Os temas do "novo" e da "reconstrução" informam o enredo que estrutura a narrativa sobre 0 vale do rio Doce, situando-o no "minimum temporal" que separa o Brasil de antes e o Brasil do futuro, ou seja, o vale do rio Doce aparece no discurso como garantia desse futuro. Pode-se ler isso no discurso de Getúlio Vargas, proferido em fevereiro de 1931, em Belo Horizonte, capital de Minas Gerais.

Creio poder afirmar que a grandeza futura do Brasil depende, principalmente, da exploração de suas jazidas de ferro. 0 ferro é fortuna, conforto, cultura e padrão, mesmo, da vida em sociedade. Por seu intermédio, abastecemse de água as cidades e irrigam-se as lavouras. Dele se faz a máquina, e é força. Por ele se transporta a energia, florescem as indústrias, movimentam-se as usinas. Na terra, sobre fitas de aço, locomotivas potentes encurtam distâncias e aproximam regiões afastadas, que permuta, com rapidez os seus produtos. Sobre as águas, é do navio a força propulsora que 0 aciona, fazendo-0 singrar velozmente mares e rios. No ar, é o motor do aeroplano

\footnotetext{
${ }^{72}$ Fusco, Rosário. Papel social dos moços (à margem do discurso do Presidente Getúlio Vargas, dirigindo aos acadêmicos paulistas). Cultura Política, Rio, 2 (11): 100105, jan., 1942. p. 104)

${ }^{73}$ Santos, 1988, p.194-195.
} 
mantendo-0 em equilíbrio e aligeirando-Ihe o voo. É, finalmente, a trave do teto, o lume para o lar e, ao mesmo tempo, a arma para a defesa da Pátria. ${ }^{74}$

A reportagem especial de CP inicia definindo o que era o "presente de ontem": paralisia causada pelo contrato assinado pelo presidente da República Epitácio Pessoa, em 1920, e Percival Farquhar, em nome da Itabira Iron. 0 contrato teria servido tão somente para agitar "a opinião pública do Brasil de 1920 a 1937 ". Para CP, a Comissão de Justiça da Câmara dos Deputados, que analisou o contrato em 1926, teria produzido um "documento sensacional", reprovando o contrato. 0 documento sensacional era 0 relato do deputado Francisco Campos (Minas Gerais), porém não é de se estranhar o voto contrário, sabendo-se da oposição radical dos mineiros ao contrato. Na verdade, o que se pretende na reportagem é destacar que entre os membros comissão se encontrava Getúlio Vargas: "a primeira vez em que o nome do atual Presidente aparecia ligado a um dos problemas mais decisivos do futuro brasileiro e ao qual teria, muitos anos depois, de reportar-se em última instância para decretar a independência econômica nacional". (CP, 1943, p. 125-126).

A revista CP afirma estar o futuro do Brasil preso ao do vale do rio Doce, pelo "valor econômico que the está reservado". Os recursos minerais e "toda essa área coberta de matas virgens e o seu sistema hidrográfico representa um riquíssimo potencial de produção agrícola, pecuária e florestal” (CP, 1943, p. 128; 129). A ideia de um "riquíssimo potencial" era um lugar comum nas representações sobre 0 vale do rio Doce e, ao longo da reportagem, CP contribui para essa idealização. Relembrando o romance do modernista brasileiro Graça Aranha, que se passa no vale do rio Doce, CP afirma ser o título "Canaã" uma realidade, pois se trata de "um verdadeiro vale bíblico". No passado as tentativas de colonização não tiveram sucesso ou nem foram tentadas, pelas dificuldades que "amedrontavam os exploradores mais audazes". Esse recuo no tempo tem como objetivo realçar a importância do "momento atual" para o vale do rio Doce e o Brasil. A revista CP procura monstra o "caso Farquhar", controvérsia central de "palestras, discussões, conferências, entrevistas, discursos, mesmo parlamentares, e até livros", como um impasse que atrasava o futuro do Brasil. Realça a oposição do governo de Minas Gerais, cujo contrato aprovado em 1927, pelo presidente Antônio Carlos, foi revogado no ano seguinte pelo novo presidente Olegário Maciel. (CP, 1943, p. 132 e 133)

0 número seguinte, de janeiro de 1944 , publicou a segunda parte da reportagem especial de Cultura Política. Logo de início traz o trecho do discurso proferido por Getúlio. Vargas, na capital de Minas Gerais, em fevereiro de 1931, mencionado acima. Apesar de 0 discurso abordar várias questões, o trecho considerado um "verdadeiro credo nacionalista" tem como objetivo demostrar o acerto do governo federal em separar a questão siderúrgica da questão da exportação de minério. Isso era uma operação muito delicada, pois contrariava diretamente o ponto de vista dos mineiros, cuja tese se fundamentava na vinculação das duas questões. 0 sentido político da visita a capital de Minas Gerais e o objetivo do discurso são muito evidentes: era preciso criar as condições políticas para se efetivar o propósito do governo federal. Para CP (1944, p. 268 e 271) o vale do rio Doce mobilizava todos "os anseios da consciência brasileira pelo ideal de grandeza". Não se tratava de "aconselhar o repúdio ao capital estrangeiro", pois esse teria um papel a cumprir "no desenvolvimento das nossas riquezas naturais". Entretanto, ele deveria ser evitado no caso do ferro, visto sua importância para a soberania nacional.

A tese central de CP, 'em sua reportagem especial, pode ser expressa da seguinte forma: Getúlio Vargas solucionou o problema que era fundamental para a "emancipação da economia nacional", ao separar a questão da exportação de minério, criando a Companhia Vale do Rio Doce, e a questão da implantação da grande siderúrgica, criando a Companhia Siderúrgica Nacional. A continuação da reportagem traz duas imagens, que longe de serem apenas ilustrações, procuram oferecer provas para o leitor sobre o "novo Brasil". A primeira ilustração mostra um navio cargueiro atracado junto ao silo de minério de ferro. A legenda informa que a ilustração era para dar ao leitor "uma ideia do funcionamento do silo para embarque de minério no porto de Vitória". Podese observar na ilustração uma representação do futuro (progresso) e, portanto, ficava demonstrado 0 acerto da tese de CP. Imagem e legenda mostram enormes instalações em aço e concreto do silo, no qual se armazenará 0 minério de ferro que será levado diretamente ao navio cargueiro, a uma "velocidade de 1.200 toneladas por hora". A proporção da grandeza das estruturas do porto é dada pelo navio cargueira atracado, que fica pequeno em vista do conjunto.

${ }^{74} 0$ discurso foi proferido em fevereiro de 1931, com o título de "Os saldos ouro e o problema siderúrgico". É possível encontrar uma análise em BARROS, 2012. 
Mantendo a estrutura que caracteriza a prática discursiva da revista $\mathrm{CP}$, conforme mencionamos antes, a reportagem estabelece 0 contexto histórico para afirmar que coube a Vargas finalizar "a pendência que durante vinte anos empolgou os círculos administrativos, técnicos e políticos do país" (CP, 1944, p. 272). Getúlio Vargas encerou o "caso Farquhar", com o Decreto-Lei n. 1.507, de 11 de agosto de 1939, que declarou irrevogavelmente a caducidade do contrato de 20 de maio de 1920, entre a Itabira Iron Ore Company Limited e o Governo Federal. A partir desse ponto, CP desenvolve um enredo que se tornará orientador de diferentes discursos e narrativas construídas sobre 0 assunto, garantindo-Ihe uma unidade comum, inclusive nos escritos acadêmicos posteriores. Os subtítulos funcionam como um plano de redação capaz de produzir o "fato histórico", cujo protagonista principal é o Estado.75 Algumas ideias sobressaem, nos diversos subtítulos, principalmente as que se referem a0 papel do Estado para o desenvolvimento dos recursos naturais do Brasil e a importância do vale do rio Doce no projeto nacional. (CP, 1944, p. 273 a 279).

Na estrutura estabelecida pelo enredo, os subtítulos se dividem em duas partes: a primeira busca construir o "fato histórico" da solução da questão da exportação do minério de ferro e da siderurgia, que se arrastava a anos; o conjunto de subtítulos tem a função é demostrar a importância do vale do rio Doce para a efetivação da solução. 0 subtítulo "0 caminho do rio Doce ảbre uma nova era para a humanidade", com seu exagerado ufanista, foi extraído de uma passagem do discurso do ministro da fazenda Sousa Costa, responsável pela assinatura dos Acordos de Washington, proferido em Belo Horizonte, para comunicar os termos desses acordos. Para o ministro os acordos permitiriam construir a estrada de ferro para a exportação da "riqueza até hoje em estado potencial". 0 discurso do ministro é utilizado para CP fundamentar a tese de que o vale do rio Doce seria mais que 0 caminho de Minas para o mar, seria o caminho do Brasil central, ou seja, a integração entre o litoral e o hinterland. Sousa Costa criticou aqueles que enaltecem as riquezas naturais do Brasil, mas se esquecem da "angústia geográfica da terra que habitamos", que dificultam a "penetração fluvial", exceto para o Amazonas. 0 rio Doce não seria diferente, porém ele possuía um vale que oferecia a solução.

Portanto, não era o rio propriamente dito que teria importância, pois não ofereceria condições para o fluxo de mercadoria, pelas suas cachoeiras e irregularidades. Entretanto, a geografia particular do seu vale, penetrando profundamente no hinterland, seria o leito para se assentar a moderna estrada de ferro. 0 vale, esse sim, seria 0 "caminho natural para o fluxo e refluxo das matérias primas, vindas do mar e das que se escoam do interior". A outra ilustração utilizada na segunda reportagem tem o título de "Acesso ao Brasil Central", na qual se destaca a região sudeste e as dificuldades que as ferrovias enfrentavam para ultrapassar as serras do Mar e da Mantiqueira, exceto da EFVM. Comparando com as outras ferrovias, a EFVM não encontraria barreiras naturais para dar acesso ao Brasil Central. 0 destaque é para as rampas de apenas 1\% (ou seja, a cada 100m de percurso a altitude se eleva apenas a um metro). Essa vantagem, "do ponto de vista econômico", seria de importância fundamental.

Utilizando trechos do discurso do ministro da fazenda Sousa Costa, a revista CP constrói uma narrativa da integração do território na ótica da escala estatal, base necessária da comunhão nacional e integração do hinterland aos grandes centros. Com as referências na fala do ministro, CP afirma que a integração nacional seria realizada pela combinação entre rodovia e ferrovia. Por outro lado, procura realçar que o estado de Minas Gerais seria beneficiado pelos Acordos de Washington e pela criação da Companhia Vale do Rio Doce. Cultura Política transcreve 0 trecho no qual o ministro elogia o governador Benedito Valadares como precursor do novo tempo, ao inaugurar, em 1934, a estrada de rodagem que ligou Teófilo Otoni ao município de Governador Valadares, "criado pela evolução milagrosa, em quatro anos, do antigo lugarejo de Figueira". 0 ministro realça que os 200 quilômetros construídos "em matas virgens penetram em regiões desconhecidas e unem o Brasil ao Brasil".

Não é sem razão a referência feita pela revista Cultura Política, em sua reportagem especial, aos discursos de Getúlio Vargas, proferido em 1931, e do ministro Sousa Costa, ambos em Belo Horizonte, capital do estado de Minas Gerais. A oposição mineira se fundamentava na tese de que a exportação de minério deveria se vincular a implantação da siderurgia no vale do rio Doce. A solução encontrada pelo governo federal não atendia aos anseios dos mineiros e, consequentemente, permanecia a "questão mineira", que associava exportação do minério de ferro; implantação da siderurgia; crítica interna do atraso econômico em relação ao estado de São Paulo; e, finalmente, expectativa de um desenvolvimento integrado de Minas Gerais. Os mineiros não desejavam outro ciclo do ouro. ${ }^{76}$

\footnotetext{
75 "Benefícios proporcionados pela guerra"; "A Terceira Reunião de Consulta"; "Os acordos de Washington"; "A proposta Sousa Costa"; "A resposta de Sumner Welles"; "A significação dos acordos e a atitude da Inglaterra"; e, finalmente, "Organização da Companhia Vale do Rio Doce S.A.".

${ }^{76}$ Espíndola, 2013, p. 276-277).
} 
Em 1931, 0 discurso de Vargas buscava criar um clima favorável à proposta de tirar dos estados o controle sobre exportações. Esse tinha sido o único trunfo com o qual o governo de Minas Gerais conseguira paralisar a Itabira Iron, ao colocar valores que inviabilizavam as vendas de minério de ferro no exterior. Getúlio Vargas oferecia em troca do direito que seria retirado a promessa de que caberia ao estado de Minas Gerais o destino sobre 0 ferro e a siderurgia (BARROS, 2012). Esse compromisso não se cumpriu: quando do discurso de Sousa Costa, proferido em Belo Horizonte, já estava decido construir a grande siderúrgica no vale do Paraíba, no estado do Rio de Janeiro. A "questão mineira" não apenas explicaria o esforço do ministro Sousa Costa, indo pessoalmente dar satisfação aos mineiros sobre os acordos assinados com os EUA, como também a visita de Getúlio Vargas ao vale do rio Doce, em 1940.

0 presidente Vargas, além de jornalistas cariocas, se fez acompanhar de grande comitiva, que incluiu nomes fortes do regime, tais como o ministro Eurico Gaspar Dutra, o general Horta Barbosa, Lourival Fontes, Edmundo de Macedo Soares, entre outros. A visita a Minas Gerais foi anunciada, como antecedência, destacandose que o presidente teria "oportunidade de excursionar por uma das mais ricas regiões do Estado, 0 Vale do Rio Doce". ${ }^{77}$ A comitiva do presidente partiu de Belo Horizonte, em viagem ferroviária, acompanhada pelo governador Benedito Valadares e todo o secretariado do governo de Minas Gerais. ${ }^{78}$ No dia 14 de maio, a comitiva chegou à cidade de Governador Valadares, onde também se fez presente o interventor do Espírito Santo, Punaro Bley. 0 prefeito local, Moacir Paleta decretou feriado municipal, incentivando a população a acompanhar de perto 0 desenrolar da visita presidencial. Na cobertura jornalística o vale do rio Doce é apresentado como a "rica zona do Rio Doce". A imprensa destaca os temas que teriam ocupado a pauta do presidente: 0 transporte de minério para exportação e a construção da grande siderúrgica. Também realça a importância das rodoviárias, afirmando ser a estrada de rodagem entre Governador Valadares e Teófilo Otoni uma das mais importantes do país. ${ }^{79}$

0 vale do rio Doce está no centro do que se denomina aqui de "questão mineira". Daí a maneira cuidadosa com que Getúlio Vargas tratou o "problema siderúrgico". A presença do próprio presidente, acompanhado de uma comitiva expressiva e de todo governo do estado de Minas Gerais, é indicativa do cuidado que a questão exigia no campo político. Uma semana depois a imprensa noticiava a visita a Minas Gerais do Diretor do Departamento Nacional do Café, Osvaldo Barros, com destaque o trecho do seu pronunciamento que se refere ao vale do rio Doce: "Dentro de breves anos, essa rica zona será um verdadeiro celeiro do Brasil". ${ }^{80}$ Depois da assinatura dos Acordos de Washington, mesmo contanto com pleno apoio do governador Benedito Valadares, Getúlio Vargas tratou de enviar a Belo Horizonte o ministro Sousa Costa. Todo cuidado era necessário, visto o desmembramento promovido pelo poder central entre a exportação de minério e a construção da grande siderúrgica. Isso atendia a política nacional, porém contrariava a posição que os mineiros defendiam a três décadas: para os mineiros a questão não estava resolvida. Mais uma fez é oferecida promessa, como se vê na continuidade da reportagem especial de Cultura Política (CP 4, n. 36, p. 282-283):

Todo 0 vale do rio Doce receberá influencia benéfica dessa valorização substancial'e alcançará um progresso que escapa, no momento, a qualquer apreciação por mais otimista que seja. Tornar-se-á, pois, um forte centro produtor e, correlatamente, um poderoso centro consumidor. Há, ainda, a considerar que 0 excesso dos lucros da Companhia [Vale do Rio Doce], sempre que exceder dos quinze por centro de dividendo, será invertido em melhoramentos de toda a zona de sua influência. Esta constituirá uma ação direta de valorização da zona servida pela Estrada de Ferro Vitória a Minas. [...] A Conquista e povoamento do vale do rio Doce avançam à proporção que se aceleram as atividades da nossa empresa, iniciadas há pouco mais de um ano. (CP, 1944, p. 285).

A referência à Companhia Vale do Rio Doce como "nossa empresa" não passa despercebida, pois tem um sentido forte de nacionalidade: é nossa porque é do Brasil, dos brasileiros e do novo tempo de desenvolvimento; a companhia é da nação e dos mineiros. Para CP, 0 ar de "far-west" que se via no vale do rio Doce era sinal positivo das transformações aceleradas que caracterizam a força "criadora dos pioneiros". 0 binômio novo-

\footnotetext{
77 A Batalha, de de maio de de 11 Disponível «http://memoria.bn.br/DocReader/Hotpage/HotpageBN.aspx?bib=175102\&pagfis=20014\&pesq=\&url=http://memoria.bn.br/docreader». Acesso em: 9 jul. 2015.

${ }^{78}$ No dia 13 de maio o presidente visitou as instalações da Companhia Siderúrgica Belgo-Mineira, em João Monlevade; e a cidade de Itabira, cujas importantes reservas de minério de ferro estavam no controle da Itabira Iron, especialmente o pico Cauê.

$\begin{array}{rllllll}79 & \text { B } & \text { Batalha, } & \text { de } & 15 & \text { de } & \text { maio de }\end{array}$ «http://memoria.bn.br/DocReader/Hotpage/HotpageBN.aspx?bib=175102\&pagfis=18942\&pesq=\&url=http://memoria.bn.br/docreader\#». Acesso em: 10 jul. 2015. 80 A Batalha. Rio de Janeiro, 23 de maio de 1940, p. 3. «http://memoria.bn.br/DocReader/Hotpage/HotpageBN.aspx?bib=175102\&pagfis=20014\&pesq=\&url=http://memoria.bn.br/docreader». Acesso em: 10 jul. 2015. .
} 
reconstruir se manifestava também aqui, pois as mudanças promoviam também o "ressurgimento do vale do rio Doce", que até então era despovoado e esquecido, era um "plano grandioso" que havia se tornado possível. 0 vale do rio Doce era a chave do novo tempo para Brasil, para Minas Gerais e todo o Brasil Central, pois era o ponto de união e integração nacional.

Pois bem, a bacia do rio Doce além de parecer indicada pela Natureza para a penetração no interior do Brasil, portanto, no sentido de desenvolver essa civilização, também o é no sentido do Norte. Desenvolvida a bacia do rio Doce, teremos caminhado com essa economia na direção do Norte, no ideal de conseguirmos uma uniformidade de civilização em nossa Pátria. (CP, 1944, p. 285).

A partir do Estado, dois movimentos se impuseram à bacia do rio Doce: a) na pequena escala sobressai 0 projeto nacional de implantação da infraestrutura ferroviária, rodoviária e industrial (mineração e siderurgia); b) na grande escala trabalharam os geógrafos do CNG/IBGE, porém informados pelas expectativas de progresso que se esperava do vale do rio Doce. Os trabalhos produzidos pelos geógrafos, independentes das expectativas, revelam uma realidade muito mais complexa, do que aquela vista da pequena escala. Os geógrafos encontram uma diversidade que impedia o estabelecimento de homogeneidade mínima, capaz de permitir os efeitos integradores desejados pelo projeto nacional. Foram comentários críticos colocados esparsamente nos textos, porém foram eles que se confirmaram nas décadas seguintes. A realidade não caminhou no sentido prometido pelo discurso, pois as atividades econômicas (mineração, siderurgia, extrativismo vegetal e culturas agrícolas) não provocavam o desenvolvimento regional integrado nem criavam uma rede de cidades interligadas.

Os estudos dos geógrafos, discursos políticos, publicações oficiais e narrativas locais, nas décadas de 1940 e 1950, enquadrados pelo enredo e pela escala nacional, deixaram de lado as tensões e conflitos causados pela entrada de atores externos, que representavam os grandes investimentos de capital: em mineração (ferro e mica), siderurgia e hidroelétricas; em obras de infraestrutura (reforma da EFVM, para transporte de minério em grande escala, e construção da rodovia federal Rio-Bahia - BR 116); no negócio madeireiro, particularmente por firmas do Rio de Janeiro e Belo Horizonte; e na exportação de gado bovino para o Rio de Janeiro. Também ficaram de fora as tensões e conflitos provocados, a partir de 1942, pela ação de médicos, engenheiros, cientistas sociais e técnicos, brasileiros e americanos, que atuaram no saneamento, nas duas frentes: no sentido Leste-Oeste, ligada ao Serviço Especial de Saúde Pública (SESP), que atuou nas áreas vinculadas à EFVM, ao minério de ferro e à produção de mica; outra frente no sentido Sul-Norte, ligada ao Departamento Nacional de Estradas de Rodagem (DNER), que atuou nas áreas cortadas pela rodovia federal Rio-Bahia. ${ }^{81}$

A solução dada pelo Estado Novo, separando a questão siderúrgica da exportação do minério de ferro, não atendeu aos mineiros. A "questão mineira" somente foi resolvida, em 1962, com a inauguração das Usinas Siderúrgicas de Minas Gerais S.A - Usiminas, criada em 25 de abril de 1956, menos de três meses depois de 0 mineiro Juscelino Kubitschek ser empossado na Presidência da República. A década de 1960 foi marcada pela euforia causada pelo início da produção da grande siderúrgica Usiminas, utilizando o coque no lúgar do carvão vegetal. Entretanto, os dados da década de 1960 não confirmam as expectativas para a bacia do rio Doce, pois indicam uma inversão das curvas de expansão econômica e demográfica, que declinam acentuadamente. A primeira vista pode parecer estranho, porém os estudos dos geógrafos do CNG e IBGE indicavam a tendência de médio prazo de esgotamento da capacidade da região reter população e manter o ritmo da atividade econômica. As diferentes temporalidades que encontraram entre as oito regiões e 16 zonas, nas quais dividiram a bacia do rio Doce, forneceram indicadores que apontavam para a tendência de esgotamento. ${ }^{82} \mathrm{Na}$ década de 1970, no auge do milagre econômico da ditadura militar no Brasil, surgiu uma nova expectativa de "revitalização" da economia do vale do rio Doce, com os grandes investimentos em produção de celulose e eucalipto (Celulose Nipo-Brasileira S.A., no médio rio Doce; Aracruz Celulose S.A., no baixo rio Doce). Entretanto, na década de 1980, não apenas prevaleceu a tendência apontada antes, como houve uma maior intensidade do processo de inflexão econômica descendente e crise estrutural, com o declínio da pecuária de corte, num quadro generalizado de lixiviação, erosão e esgotamento dos solos. ${ }^{83}$

\footnotetext{
${ }^{81}$ Espíndola, 2013, p. 277

${ }^{82}$ Strauch, 1951

${ }^{83}$ Minas Gerais. Energia e Transporte, Aspectos Sociais e Regionais. In.: Economia mineira - 1989; diagnóstico e perspectivas. Belo Horizonte, BDMG, v. 5, 1989
} 
Água, matas e minérios foram fatores decisivos para se submeter a bacia do rio Doce às escalas estadual, nacional e internacional. A dinâmica local foi alterada e submetida à lógica externa pela força do capital e poder do Estado. As promessas de desenvolvimento duradouro, das décadas de 1940 e 1950, não se confirmaram e, pelo contrário, centenas de milhares de pessoas, que anteriormente havia ocupado a bacia do rio Doce, se viram obrigadas a migrar para outras regiões do Brasil, para as grandes cidades e para 0 exterior. ${ }^{84} \mathrm{Hoje}$, a bacia hidrográfica do rio Doce é uma das mais degradadas do estado de Minas Gerais, conforme dados oficiais do estado de Minas Gerais. ${ }^{85}$ A história ambiental, portanto, tem um papel significativo no debate sobre sustentabilidade ambiental, pois é preciso questionar os danos infligidos ao ambiente pelos grandes investimentos de capital (siderurgias, mineradoras, carvoarias, ferrovias, rodovias, celuloses e reflorestamentos) e pelo poder estatal. Também se faz necessária a autocrítica, pois cabe aos atores locais se questionarem sobre os valores, ideias e atitudes em relação a natureza.

0 estado de Minas Gerais não tem mar, porém diz o mito que o povo mineiro quando não vai a praia fica agoniado. Ele sempre procura o mar, como se lê no discurso do governador do Espírito Santo, Jones dos Santos Neves, proferido no Senado, em 1948: "como se estranha nostalgia de velhas e remotas aventuras náuticas despertassem o espírito aventureiro da nobre gente montanhesa e a compelisse, inexoravelmente, para os largos caminhos do oceano". ${ }^{86}$ Em julho de 2015 um dos mineiros não conseguiu chegar ao mar: "A agonia do maior curso d'água do Sudeste brasileiro chegou ao patamar mais crítico da história". Sem força, o rio Doce parou "60 metros continente adentro e se encontra agora como uma lagoa, represada por uma faixa de areia grossa de dois metros de altura".

\footnotetext{
${ }^{84}$ Soares, 2002. Weber. Da Metáfora à Substância: redes sociais, redes migratórias e migração nacional e internacional em Valadares e Ipatinga. Belo Horizonte, CEDAPLAR /UFMG, 2002. (Tese de Doutorado).

${ }^{85} 0$ portal "meioambiente.mg" das Secretaria de Estado de Meio Ambiente e Desenvolvimento Sustentável (Semad) de Minas Gerais informa que a bacia do rio Doce, que "abriga o maior complexo siderúrgico da América Latina, além de ser grande produtora de minério de ferro", é a bacia hidrográfica mais degradada do ponto de vista ambiental. Disponível em: «http://www.igam.mg.gov.br/banco-de-noticias/1-ultimas-noticias/307-convenio-para-recuperar-rio-doce-beneficiara-31-milhoes-depessoas» Acesso em: 10 jul. 2015.

${ }^{86}$ Discurso proferido no Senado Federal, a 23 de maio de 1948, por Jones dos Santos Neves, governador do Espírito Santo, sobre a questão de limites com Minas Gerais, com risco de "conflito armado" por causa de "antagonismo inconciliável". «http://www.estacaocapixaba.com.br/personalidades/jones santos neves/discursos/discurso 7.html» Acesso em: 1 mar. 2015.
} 